\title{
BACTERIAL LEAF BLIGHT (BLB) DISEASE INCIDENCE AND SEVERITY IN BASMATI AND NON-BASMATI RICE GROWING AREAS OF PUNJAB, PAKISTAN
}

\author{
aHafiz M. I. Arshad, bJunaid A. Khan, aKamran Saleem, asyed S. Alam, 'Shahbaz T. Sahi \\ ${ }^{a}$ Plant Protection Division, Nuclear Institute for Agriculture and Biology (NIAB), Jhang Road, Faisalabad, Pakistan. \\ ${ }^{b}$ Pakistan Institute for Engineering and Applied Sciences. Islamabad, Pakistan. \\ c Department of Plant Pathology, University of Agriculture, Faisalabad, Pakistan.
}

\section{ART ICLE I N F O}

\section{Article history}

Received: September 14, 2020

Revised: December 13, 2020

Accepted: December 28, 2020

\section{Keywords}

Diseases

Yield

Epidemic

Basmati rice

Bacteria

\section{A B S T R A C T}

Bacterial leaf blight (BLB) is one of the most damaging diseases of rice in Asia and annually incurring significant yield loss to rice production in Pakistan. Management of disease required the information of BLB incidence and severity in basmati and non-basmati rice areas. The current study presented the observation of BLB disease incidence and severity in 19 major rice growing districts of Punjab. In this study, 9 Basmati growing and 10 non-basmati rice growing districts were surveyed from September to October in 2009, 2010, 2012, and 2013. Rice fields near to roadside, research stations and adjoining farmer fields were preferred for the survey. Each halt was after $10 \mathrm{~km}$ on the route depending upon the crop intensity. The general appearance of the field was observed for the absence or presence of BLB disease symptoms. The incidence of BLB was recorded as a percentage of plants infected in a field on a visual basis. For each field, 4 plants were observed at 5 points/hill along the diagonal transect for disease symptoms. The data of severity was recorded as the percentage of leaf area infected out of the total leaf area. Among the districts with basmati rice, the mean incidence of BLB was maximum in Gujranwala, Sheikhupura and Hafizabad followed by Mandi Bahauddin and Gujrat. A similar pattern of disease severity was observed in the basmati rice belt with maximum BLB mean severity in Gujranwala, Sheikhupura and Hafizabad having most of the field with a severity scale of 9. Overall, the disease trend showed that both the incidence and the severity were higher in 2010, 2012 and 2013 in the basmati rice belt. The ten districts, comprising of mostly non-basmati rice varieties showed relatively less BLB incidence and severity compared to basmati rice districts. The maximum mean incidence of 20 25\% was observed in Faisalabad, Chiniot and Sahiwal in at least one year of the rice season. None of the field with BLB disease symptoms was observed in districts Okara, Khanewal and Bahawalpur during the 2012 and 2013 rice season. Maximum disease severity of mean value 3 was observed in Sahiwal during 2009 while the rest of the districts showed less than 2 mean severity during all rice growing season. Overall, in non-basmati rice districts, no specific trend of disease incidence and severity was apparent, however, the disease was present in very low magnitude or absent during the surveyed years. The information from this study is helpful in the selection of variety for basmati and non-basmati districts of Punjab and the adoption of appropriate disease management strategies.

Corresponding Author: Kamran Saleem

Email: kammmran@hotmail.com

(c) The Author(s) 2020. 


\section{INTRODUCTION}

Rice (Oryza sativa L.) is the most important food crop of the developing world and the staple food of more than half of the world's population. Worldwide, more than 3.5 billion people depend on rice for more than $20 \%$ of their daily calories (IRRI, 2012). Pakistan is the fourth largest exporter of rice in the world and contributes $14 \%$ of the total world market (FAO Statistics, 2010). The rice crop is vulnerable to many diseases among which Bacterial Leaf Blight (BLB) incited by Xanthomonas oryzae pv. oryzae $(X \circ o)$ is the most devastating and destructive disease throughout the world (Mew, 1987; Swings et al., 1990). The disease is also a matter of serious concern in other parts of Asia (Alim, 1967; Ou, 1985). The disease was first noticed by the farmer of Japan in 1884 and cultivation of high yielding but susceptible rice cultivars was a major reason of BLB in Asia (Wang et al., 2000). Among the top ten plant pathogenic bacteria, Xanthomonas oryzae pv. oryzae (Хоo) is at the fourth position based on the scientific/economic importance (Mansfield et al., 2012). Yield loss of $10-20 \%$ are common and have been as high as $74 \%$, depending upon location, season, weather, growth stage of the crop and cultivar (Mew et al., 1993; Ou, 1985). Seed borne nature of this pathogen makes it an important quarantine organism in many countries (Reddy and Reddy, 1990).

Thus seed-borne bacteria act as a primary source of inoculum which may lead to an epidemic condition in the field. A seed infection usually occurs during the three distinct phases of seed production, seed development and seed maturation; the pathogen can infect the seed and developing plant leading to systemic infection (McGee, 1995). BLB occurs at all growth stages of the rice crop and shows either Kresek or leaf blight symptoms. As the plant progresses towards panicle emergence, the sterility percentage and number of immature grains increases. Under severe infection, there may be $50 \%$ yield reduction depending on the stage of the crop, degree of cultivar susceptibility and to a great extent, the conduciveness of the environment in which disease occurs (Ou, 1985).

In Pakistan, BLB was reported first in 1977 and afterwards, in 1987, it was reported in all provinces of Pakistan (Akhtar and Akram, 1987). The disease starts with the yellowing of leaves, usually move from tip to downward, followed by the death of infected leaf tissues and its infection at tillering stage of the crop can lead to $100 \%$ yield loss (Mew and Majid, 1977). Incidence of
BLB is increasing in recent years especially in Kaller belt that is famous for producing high-quality basmati rice. BLB was observed in patches showing 5-10\% disease incidence in 1997 in districts Sheikhupura, Gujranwala and Hafizabad, while in some other fields of nearby villages $70-80 \%$ or even $90-95 \%$ infection was observed showing severe epidemic (Khan et al., 2000). The disease reappeared in epidemic form during 2007 and 2008 which knockdown all available commercial varieties (Khan et al., 2009). Resistant cultivars become susceptible after a few years because of high momentum in virulence of the pathogen. Continuous observation of disease throughout the crop season and sources of pathogen survival during off-season can facilitate in adopting management strategy. Monitoring of disease in farmer field as well as at research stations or farms elucidated the appearance of new races; new varieties and fungicide opt by the farmer. In this regard, the present survey was conducted during 2009, 2010, 2012 and 2013 for monitoring the BLB disease prevalence, incidence and severity in 19 major rice growing districts of Punjab province. Disease samples were collected for isolation and characterization of the pathogen.

\section{MATERIALS AND METHODS}

Nineteen rice growing districts of Punjab i.e. Narowal, Sialkot, Gujranwala, Sheikhupura, Hafizabad, Gujrat, Mandi Bahauddin, Lahore, Nankana, Faisalabad, Chiniot, Toba Tek Singh, Sahiwal, Pakpatan, Vehari, Bahawalnagar, Okara, Khanewal and Bahawalpur were surveyed during $15^{\text {th }}$ September to $15^{\text {th }}$ October 2009, 2010, 2012 and 2013 (Figure 1). Rice fields near to roadside, research stations and adjoining farmer fields were preferred for the survey. In each district number of locations visited depended upon the cropping intensity. Each halt was after $10 \mathrm{~km}$ on the route depending upon the crop intensity. The general appearance of the field was observed for the absence or presence of BLB disease symptoms.

Incidence of BLB was recorded as percentage of plants infected in a field on a visual basis (IRRI, 1996). For each field, plants were observed 5 points/hill along the diagonal transect. 4 plants at each point/hill were observed for disease symptoms. Incidence of a field was calculated with the help of following formula:

BLB incidence $\%$ age $=\frac{\text { Number of BLB infected Plants }}{\text { Total number of Plant observed }} \times 100$ The data of severity was recorded as percentage of leaf area infected out of total leaf area. For scoring BLB severity in 
the field, 0-9 scale was used i.e. 0: no disease. 1: 1-5\%, 3: 612\%, 5: 13-25\%, 7: 26-50\%, 9: 51-100\% (IRRI, 1996).

Upper 3 leaves of each plant from each field were collected. It forms a composite and representative sample was taken for isolation. Infected tissues were cut into $2 \times 7$ $\mathrm{mm}$ section from advancing portion of the lesion, sterilized in $70 \%$ alcohol for $1 \mathrm{~min}$, placed in Peptone Sucrose Agar (PSA) medium and incubated at $28{ }^{\circ} \mathrm{C}$ for $48-72$ hours. Isolated colonies were purified and the pathogen was confirmed through pathogenicity and biochemical tests. Association between BLB incidence, severity and prevalence was also determined for each year.

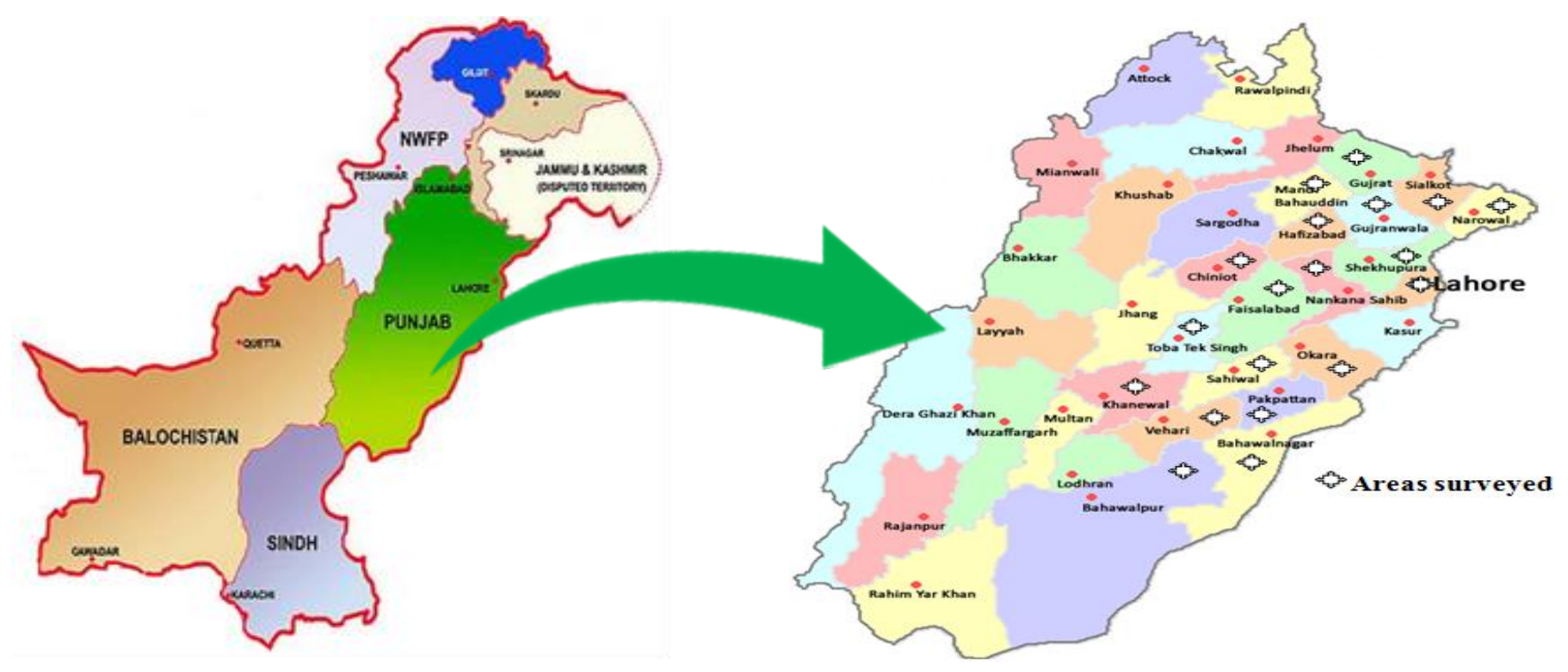

Figure 1. Geographical areas of Punjab surveyed for monitoring of BLB disease of rice.

\section{RESULTS}

Surveys of nineteen rice growing districts of Punjab ( 9 basmati and 10 non-basmati rice growing districts) were conducted during 2009, 2010, 2012 and 2013. In basmati rice belt, the incidence of BLB disease was maximum in Gujranwala, Sheikhupura and Hafizabad with the range of $0-100 \%$ followed by Mandi Bahauddin (Table 1). Similar disease pattern in these districts was observed during the four years when the comparison of the mean incidence of BLB was carried out (Figure 2). Mean incidence of BLB was high in hotspot districts (Gujrawala, Sheikhupura, Hafizabad) followed by Mandi Bahauddin. The severity of BLB was also observed during the survey and recorded according to the scale of Standard Evaluation System for Rice (IRRI, 1996) based on the infected leaf area. Like BLB incidence, severity was maximum in Gujranwala, Sheikhupura and Hafizabad with the range of 0-9 followed by Nankana (Table 1). BLB severity is constant or in increasing trend in all district from 2009 to 2013 (Figure 2). Range, as well as mean of severity, were maximum in hotspot districts (Gujranwala, Sheikhupura and Hafizabad) indicating large area severely infected with BLB disease.

In 10 districts grown with non-basmati rice, BLB incidence was minimum in Bahawalnagar, Okara, Khanewal and Bahawalpur. In district Faisalabad, BLB was high during 2009 and 2010 while observed significantly low during 2012 and 2013 (Figure 3). Difference in disease pattern in Faisalabad, Bahawalnagar, Okara, Khanewal and Bahawalpur was may be due to different climatic zone. District Toba Tek Singh, Sahiwal, Pakpatan and Faisalabad showed high disease during 2009 and 2010 but drastically low disease during 2012 and 2013. In Okara, Khanewal and Bahawalpur, none of the surveyed field showed BLB disease symptoms. Trend of BLB severity is different than that of incidence. Maximum severity was observed in Sahiwal during 2009 followed by Faisalabad and Vehari. Minimum severity was recorded in districts Pak Patan, Okara, Khanewal and Bahawalpur. No specific trend in BLB severity with respect to year was observed. Overall non-basmati rice growing areas showed less BLB disease compared to basmati belt of Punjab. 
Table 1. Range of Incidence and Severity of Bacterial leaf blight of rice in Punjab during 2009, 2010, 2012 and 2013.

\begin{tabular}{lcccccccc}
\hline \multirow{1}{*}{ Districts } & \multicolumn{4}{c}{ Incidence (\%) } \\
\cline { 2 - 8 } & 2009 & 2010 & 2012 & 2013 & 2009 & 2010 & 2012 & 2013 \\
\hline Narowal & $0-30$ & $0-50$ & $0-50$ & $0-100$ & $0-5$ & $0-7$ & $0-6$ & $0-9$ \\
Sialkot & $0-30$ & $0-60$ & $0-20$ & $0-70$ & $0-9$ & $0-9$ & $0-5$ & $0-8$ \\
Gujranwala & $0-90$ & $0-100$ & $0-100$ & $0-100$ & $0-7$ & $0-9$ & $0-9$ & $0-9$ \\
Sheikhupura & $0-75$ & $0-100$ & $0-100$ & $0-100$ & $0-7$ & $0-9$ & $0-8$ & $0-9$ \\
Hafizabad & $0-100$ & $0-100$ & $0-100$ & $0-100$ & $0-5$ & $0-9$ & $0-9$ & $0-9$ \\
Gujrat & $0-15$ & $0-50$ & $0-60$ & $0-50$ & $0-2$ & $0-5$ & $0-5$ & $0-8$ \\
Mandi Bahauddin & $0-30$ & $0-70$ & $0-70$ & $0-80$ & $0-4$ & $0-7$ & $0-5$ & $0-7$ \\
Lahore & $0-15$ & $0-10$ & $0-50$ & $0-30$ & $0-4$ & $0-4$ & $0-3$ & $0-4$ \\
Nankana & $0-70$ & $0-90$ & $0-25$ & $0-40$ & $0-9$ & $0-7$ & $0-6$ & $0-8$ \\
Faisalabad & $0-90$ & $0-100$ & $0-40$ & $0-20$ & $0-5$ & $0-7$ & $0-5$ & $0-4$ \\
Chiniot & $0-25$ & $0-5$ & $0-50$ & $0-50$ & $0-5$ & $0-1$ & $0-5$ & $0-2$ \\
T. T. Singh & $0-70$ & $0-90$ & $0-5$ & $0-10$ & $0-7$ & $0-7$ & $0-3$ & $0-5$ \\
Sahiwal & $0-100$ & $0-10$ & $0-40$ & $0-05$ & $0-9$ & $0-2$ & $0-4$ & $0-3$ \\
Pak Patan & $0-90$ & $0-10$ & $0-10$ & $0-10$ & $0-7$ & $0-1$ & $0-3$ & $0-4$ \\
Vehari & $0-30$ & $0-50$ & $0-20$ & $0-20$ & $0-9$ & $0-7$ & $0-4$ & $0-3$ \\
Bahawalnagar & $0-20$ & $0-40$ & $0-25$ & 0 & $0-5$ & $0-3$ & $0-5$ & $0-3$ \\
Okara & $0-30$ & $0-10$ & 0 & 0 & $0-7$ & $0-1$ & 0 & 0 \\
Khanewal & $0-40$ & $0-50$ & 0 & 0 & $0-7$ & $0-7$ & 0 & 0 \\
Bahawalpur & 0 & $0-10$ & 0 & 0 & 0 & $0-3$ & 0 & 0 \\
\hline
\end{tabular}

${ }^{*} 0-9$ scale for BLB severity based on leaf area infected i.e 0: no disease. 1: 1-5\%, 3: 6-12\%, 5: 13-25\%, 7: 26-50\%, 9: $51-100 \%$ (IRRI. 1996).


Figure 2. Mean Bacterial Leaf Blight incidence (A), and mean severity (B) in Basmati rice growing districts of Punjab. 


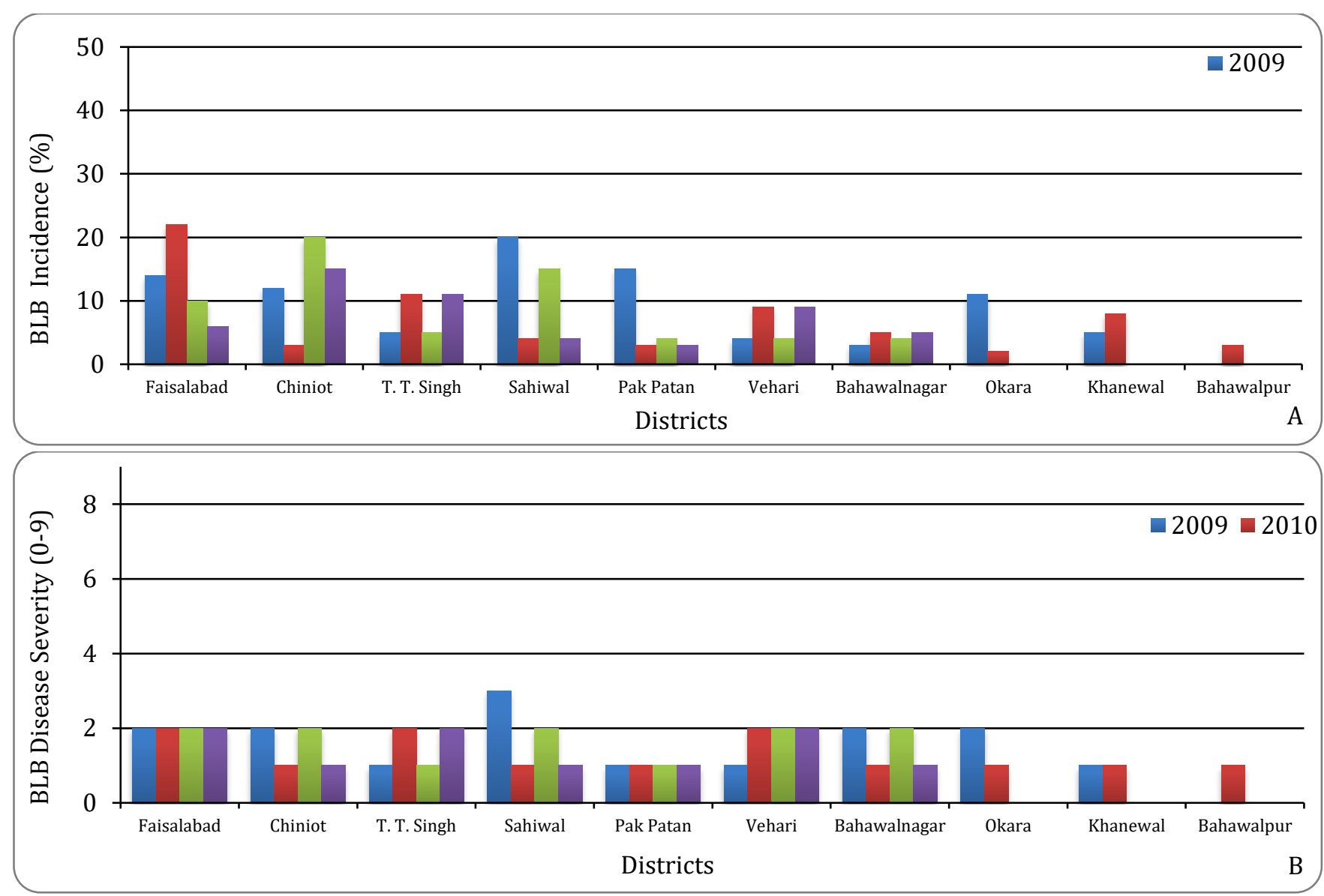

Figure 3. Mean Bacterial Leaf Blihgt incidence (A), and mean severity (B) in non-basmati rice growing districts of Punjab.

\section{DISCUSSION}

After the first report of BLB (Mew and Majid, 1977), it showed increasing trends in Pakistan especially in Kaller belt of Punjab (Khan et al., 2000). Punjab is famous for producing high quality rice mainly super basmati which is badly affected by this disease. The current study indicates the high incidence and severity of BLB in Hafizabad, Sheikhupura, Gujranwala and Mandi Bahauddin which are in line with earlier reports (Akhtar et al., 2004). The basmati rice varieties were grown on major areas of Kaller belt which are most susceptible to BLB disease. There is an increasing trend of using short-duration varieties followed by basmati varieties. Under this scenario, two crops can be grown, and more income generation is availed by the farmers, however, there is the possibility that short duration varieties serve as the inoculum source for the basmati varieties. Rice is not only cultivated in northern Punjab, but it has been extended to central and southern Punjab which is mainly a cotton belt. During the current survey, high BLB incidence was observed in Faisalabad, Sahiwal and Pakpattan in 2009 and 2010 which may be due to shifting of rice crop to these areas. Hafizabad district has diversity in pathogen population including highly virulent, virulent and less virulent isolates of BLB which is one of the reasons of high BLB incidence in Hafizabad and Sheikhupura (Arshad et al., 2017). Moreover, both Hafizabad and Sheikhupura districts are the main belt of basmati rice especially super basmati. Cultivation of different rice varieties is recommended to avoid a large epidemic.

Deployment of host resistance is the most effective and suitable approach for the management of BLB. Many resistance genes have been identified but very few were characterized in basmati varieties. The BLB pathogen has a high rate of mutation which can overcome the host resistance within the short duration of time. Identification and incorporation of new sources of resistance genes in super basmati is of priority area for rice breeders. Introduction of early maturing varieties like Kainaat, supra, basmati-386 play an important role in inoculums build up which on maturity shift the BLB inoculum storms to super basmati. BLB inoculums 
survive in rice stubbles and straw, so proper management of rice stubbles and straw is essential to avoid the chance of increasing inoculums source.

The environment also plays an important role in BLB disease. Due to high rainfall and availability of plenty of water, BLB was high in 2010, 2012 and 2013 as compared to 2009, so forecasting system of the disease needs to be established for better management of disease from nursery since maturity. Monsoon rains during the peak season of rice also favoured the BLB disease in Pakistan. The high disease incidence may also be influenced by the peasant farming cultivation methods, intermingling symptoms of BLB and leaf folder and unavailability of potent bactericides. The disease level was low in non-conventional rice districts which may be due to the different agro-climatic zone, less rainfall and intercropping with other crops. The ten districts surveyed were mainly the belt of cotton and sugarcane but now rice has been grown extensively. Such cropping pattern did not allow the pathogen to survive in off-season time resulting in low BLB incidence and severity. Although the extensive survey was conducted but some aspects that need further investigation are a source of primary inoculums and losses incurred by BLB in monetary terms at different levels of disease severity. The present study ensured the occurrence of BLB in all districts of Punjab with different levels of severity depending upon the environment and cultivated rice varieties. Since rice is an export commodity, development of BLB resistant basmati varieties is a prerequisite for successful rice production. In conclusion, variations in BLB disease incidence and severity are apparent in different rice growing areas of Punjab. It is, therefore, important that programs to develop cultivars with resistance to BLB consider other factors including the environmental conditions and cultivations practices in the area of intended cultivation. Of all the rice growing areas surveyed, Sheikhupura, Hafizabad and Gujranwala have the greatest need for BLB resistant cultivars because climatic factors in these areas favour disease development. The results mentioned above in connection with the spread of BLB in Punjab are an open challenge to the stakeholders and the scientific community of the country. It is therefore high time to monitor and adopt every measure to stop the spread of BLB in other rice producing areas of Pakistan. This report provides a baseline to stimulate the research on BLB management in Pakistan.

\section{ACKNOWLEDGEMENT}

We would like to thank Punjab Agriculture Research Board (PARB) for financial assistance that has made this survey possible.

\section{REFERENCES}

Akhtar, M. A. and M. Akram. 1987. Evaluation of national uniform rice yield trial 1985 against bacterial blight (BB) in Pakistan. International Rice Research Newsletter, 12: 12-19.

Akhtar, M. A., M. Zakria and F. M. Abbasi. 2004. Trends in occurrence of bacterial blight of rice in Pakistan. Pakistan Journal of Phytopathology, 16: 69-71.

Alim, A. 1967. Breeding of rice for resistance to major diseases in East Pakistan. Proceedings of rice disease and their control by growing resistant varieties and other measures. Tokyo, Japan, p. 199-207.

Arshad, H. M. I., K. Saleem, J. A. Khan, M. Rashid, M. Atiq, S. S. Alam and S. T. Sahi. 2017. Pathogenic diversity of Xanthomonas oryzae pv. oryzae isolates collected from Punjab province of Pakistan. European Journal of Plant Pathology, 147: 639-651.

FAO Statistics. 2010. FAO Production Year Book. Food and Agriculture Organization of the United Nations, Rome, Italy.

IRRI. 1996. Standard Evaluation System for Rice. 4th ed. INGER, Genetic Resources Center, IRRI, Manila, Philippines, p. 20-21.

IRRI. 2012. Rice Facts. International Rice Research Institute, Manila, Philippines.

Khan, J. A., H. M. I. Arshad, F. F. Jamil and S. Hasnain. 2009. Evaluation of rice genotypes against bacterial leaf blight (BLB) disease. Pakistan Journal of Phytopathology, 21: 26-30.

Khan, J. A., F. F. Jamil and M. A. Gill. 2000. Screening of rice varieties/lines against bakanae and bacterial leaf blight (BLB). Pakistan Journal of Phytopathology, 12: 6-11.

Mansfield, J., S. Genin, S. Magori, V. Citovsky, M. Sriariyanum, P. Ronald, M. Dow, V. Verdier, S. V. Beer, M. A. Machado, I. Toth, G. Salmond and G. D. Foster. 2012. Top 10 plant pathogenic bacteria in molecular plant pathology. Molecular Plant Pathology, 13: 614-629.

McGee, D. C. 1995. Epidemiological approach to disease 
management through seed technology. Annual Review of Phytopathology, 33: 445-466.

Mew, T. W. 1987. Current status and future prospects of research on bacterial blight of rice. Annual Review of Phytopathology, 25: 359-382.

Mew, T. W., A. M. Alvarez, J. E. Leach and J. Swings. 1993. Focus on bacterial blight of rice. Plant Disease, 77: 5-12.

Mew, T. W. and A. Majid. 1977. Bacterial blight of rice in Pakistan. International Rice Research Newsletter, 2: 5-19.

Ou, S. H. 1985. Rice Diseases. CAB International Mycological Institute, Kew, Surrey, U.K., pp. 62.

Reddy, M. T. S. and A. P. K. Reddy. 1990. Variability in Xanthomonas campestris pv. oryzae and their relationship to physiological characters. Annals of Agricultural Research, 11: 283-290.

Swings, J., M. Mooter, V. D. Vauterin, L. Hoste, B. Gillis, T. W. Mew and K. Kersters. 1990. Reclassification of the causal agents of bacterial blight (Xanthomonas campestris pv. oryzae) and bacterial leaf streak (Xanthornonas campestris pv. oryzicola) of rice as pathovars of Xanthomonas oryzae (Ex. Ishiyama 1922) sp. nov. nom. rev. International Journal of Systematic Bacteriology, 40: 309-311.

Wang, C., Q. Zhang, Y. Zhou, B. Zhao and K. Zhao. 2000. Assessment of genetic diversity of Xanthomonas oryzae pv. oryzae. Chinese Rice Research Newsletter, 8: 7-8.

\section{CONFLICT OF INTEREST}

The authors declare that they have no conflicts of interest.

\section{AUTHORS CONTRIBUTIONS}

H.M.I. Arshad, J.A. Khan and K. Saleem designed the study, carried out the experiment, analyzed the data and wrote the manuscript. S. Alam and S.T. Sahi contributed in designing of study and editing of manuscript. All authors have revised and approved the final manuscript.

Publisher's note: EScience Press remains neutral with regard to jurisdictional claims in published maps and institutional affiliations.

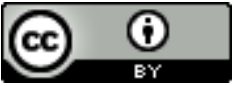

Open Access This article is licensed under a Creative Commons Attribution 4.0 International License, which permits use, sharing, adaptation, distribution and reproduction in any medium or format, as long as you give appropriate credit to the original author(s) and the source, provide a link to the Creative Commons license and indicate if changes were made. The images or other third-party material in this article are included in the article's Creative Commons license, unless indicated otherwise in a credit line to the material. If material is not included in the article's Creative Commons license and your intended use is not permitted by statutory regulation or exceeds the permitted use, you will need to obtain permission directly from the copyright holder. To view a copy of this license, visit http://creativecommons.org/licenses/by/4.0/. 